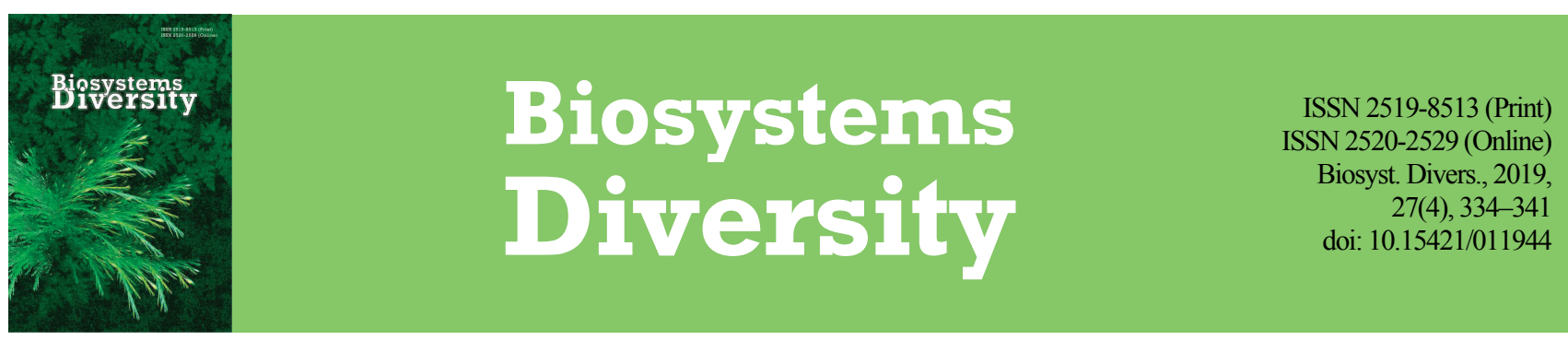

\title{
Morpho-ecological structure of oribatid mite (Acariformes, Oribatida) communities in the forest litter of recultivated areas
}

\author{
Y. Kulbachko, O. Didur, N. Khromykh, A. Pokhylenko, T. Lykholat, B. Levchenko \\ *Oles Honchar Dnipro National University, Dnipro, Ukraine
}

Article info

Received 27.09.2019

Received in revised form 02.11 .2019

Accepted 04.11.2019

Oles Honchar Dnipro National University, Gagarin Ave., 72 ,

Dnipro, 49010, Ukraine E-mail:didur@ua.fm

\begin{abstract}
Kulbachko, Y., Didur, O., Khromykh, N., Pokhylenko, A., Lykholat, T., \& Levchenko, B. (2019). Morpho-ecological structure of oribatid mite (Acariformes, Oribatida) communities in the forest litter of recultivated areas. Biosystems Diversity, 27(4), 334-341. doi:10.15421/011944
\end{abstract}

The study of morpho-ecological organization of oribatid mite communities (Acariformes, Oribatida) inhabiting forest litter of recultivated areas in steppe zone conditions of Ukraine was performed. The role of the forest and forest floor litter in optimization of the ecological situation on degraded lands was demonstrated. The function of environment creation by oribatids, as primary destructors of dead plant matter, supporting such ecosystem services as soil fertility improvement and nutrients turnover was highlighted. The research was performed within different stratigraphic types of bulk edaphotops in the recultivated plot of "Pavlogradskaya" colliery (Pavlograd, Dnipropetrovsk region, Ukraine) planted with red juniper (Juniperus virginiana L.). Withdrawal and collection of mites was performed with thermoeclector. For determination of the domination structure in the mite communities, the Engelmann scale was used. Adaptive (morpho-ecological) groups of oribatid mites were diagnosed by Krivolutsky. It was established that the number of species of oribatid mites in the forest litter of the studied red juniper plantation varied from 16 to 25 . Average density of oribatid mites varied from 4,720 to $25,327 \mathrm{ind} . / \mathrm{m}^{2}$. Among such morpho-ecological groups as soil surface inhabitants, small soil pore inhabitants, deep soil forms, floor litter inhabitants and unspecified forms, identified in the coniferous litter, the share of unspecified forms increased from loess-like loam type ( $21 \%$ of total amount) to Calcic Chernozem types with different stratigraphy $(41.0 \%, 70.0 \%$ and $70.4 \%$ accordingly). Deep soil forms in the forest floor litter of the studied red juniper plots were not identified for any of recultivation types. The obtained results expand our understanding of the role of oribatid mites in the processes of ecological rehabilitation of disturbed ecosystems in the conditions of modern nature management.

Keywords: environment rehabilitation; ecosystem services; forest recultivation; red juniper; Juniperus virginiana.

\section{Introduction}

Mining and all related activities are invariably associated with the disturbance of the top soil layer in their territories with unfavourable consequences for existence of biota, such as pollution with heavy metals of the atmosphere, water ecosystems and soils (Faly et al., 2017; Shulman et al., 2017). The mining technological process leads to soil and vegetation cover disruption, reduction of flora and fauna species variety, deterioration of fertile lands (Chakravarty et al., 2012; Klymenko et al., 2017). In particular cases, the response of natural ecosystems under anthropotechnogenic pressure can be quite sharp, leading to ultimate degradation and formation of the "industrial desert", which can be represented by mine tailings permanently exposed to wind and water erosion. At the same time, toxic compounds, which are contained in the tailings' rock, can be transferred into water ecosystems, soil and atmosphere, which negatively impact biota and the human living environment (Benbrahim et al., 2004; Faly \& Brygadyrenko, 2014) and, consequently, decrease human health potential (Pertseva et al., 2008; Lykholat et al., 2016). Therefore, in mining regions the problem of optimization of the ecological situation now is one of the top priorities (Mbaya, 2013).

To reduce the negative impact of technogenesis on the environment, a series of measures for soil conservation and vegetative cover restoration is required (Khromykh et al., 2018; Lykholat et al., 2018a). One of the solutions for this problem is forest recultivation - a series of measures comprising forest cultivation on mine rock dumps and other lands, disturbed during extraction of mineral resources from deposits (Ibarra \& de las Heras, 2005; Chibrik et al., 2016).

Forest ecosystems form the most important factor of optimizating the ecological situation on degraded lands (struggle against with erosion, dust control, accumulation of the soil organic matter, soil structure improvement, creation of conditions for species which modify habitat ecosystem engineers). In this regard, the environmental transformation role of forest tree vegetation due to its greater biomass, coverage of rock-soil strata, above-ground height, longevity and resistance against adverse factors is more effective in comparison to agricultural crops (de Waroux \& Lambin, 2012; Bertram \& Rehdanz, 2015; Borrellia et al., 2016; Mori et al., 2017; Nazarenko et al., 2018).

In artificially created forest plots on disturbed lands because of the half-illuminated, half-shadowed or shadowed light structure (Lykholat et al., 2018b), which is typical for a formed tree plantation, as well as accumulated floor litter (phytodetritus), conditions favourable for the habitat of forest plants, animals and microorganisms are created. In forest ecosystems, forest floor litter represents a special ecosystem component, other than mortmass. Living matter: algae, fungi, bacteria, viable seeds, spores, pollen, roots of higher plants, protozoa, invertebrates of different taxonomic and size groups participate, as a vital part of it, in its composition, structure and changes. Besides others, forest floor litter provides a series of vital ecological functions: regulation of air-water regime of soil, thermoisolation, protection of soil from washout and mechanical densification, it is a source of nutrient enrichment and humus formation as well. It is subjected not only to mechanical destruction, but also to intensive synthetic processes with formation of new organic compounds, enzymes or aminoacids for instance participate in it. Its significance is amplified by the fact that it represents by itself an ecological environment for many species of animals, plants and microorganisms (Chornobai, 2000; Brygadyrenko, 2016). As the result of transformation of phytodetritus, transportation of chemical compounds and elements is supported not only vertically - from living mass to soil, but also horizontally - from living mass to living mass. Study of species "ecosystem engineers" now is becoming increasingly important (Berke, 
2010; de Visser et al., 2013). Their contribution to the successful restoration of ecosystems to a desired level of necessary type of change is particularly interesting (Byers et al., 2006).

An important role among the animal population in transformation of dead plant material belongs to ecosystem engineers - animal environment-creators (Lavelle et al., 2016; Grimaldi et al., 2016, Didur et al., 2019), which contribute to soil structure formation at the most important stage - biochemical process of humification, as the result of their pedoturbation and trophic activity, which ultimately leads to transformation of forest ecosystems on recultivated plots. First of all, such representatives of mezofauna - typical saprophages as earth worms should be mentioned (Eisenhauer, 2010; Jouquet et al., 2014; Kitz et al., 2015; Cunha et al., 2016; Amossé et al., 2015), millipedes (Gudym, 2016; Pokhylenko et al., 2019), woodlice (Zimmer \& Topp, 1998; Toth et al., 2016), and particularly important representatives of microfauna - oribatid mites (Smrž \& Norton, 2004; Gormsen et al., 2006; Wehner et al., 2018). Their activity is connected mainly with provision of such important ecosystem services as increase of soil formation and nutrient turnover. Benefits for such forest ecosystems define the importance of this animal group, whose value substantially increases in modern conditions of climate change towards aridity (Stott \& Moebius-Clune, 2017) and temperature rise, especially in semiarid climatic zones (Klymenko et al., 2017).

Ecological functions of the soil can be indicators of effectiveness for optimization of technogenic landscapes. One of the mechanisms of initiation and acceleration of their recovery is participation of animals ecosystem engineers such as oribatid mites (Acariformes, Oribatida) in naturalization of forest plantations on recultivated plots. They are directly involved in processes of soil creation (Kolodochka \& Shevchenko, 2013; Shtirts, 2015), impacting directly or indirectly the velocity of decomposition of the forest litter, providing it's fragmentation and further dispersion in the above ground ecosystem (Sjursen et al., 2005; Sylvain \& Buddle, 2010; Seniczak et al., 2013) and, consequently, turnover velocity of ash elements.

Oribatid mites represent abundant and varied, ecologically and geographically widespread taxa of arthropods. They are one of the smallest groups of arthropods. Their sizes (body length) vary in the diapason 0.2 $1.5 \mathrm{~mm}$ (Walter \& Proctor, 2013). The number of oribatids is the highest in forest soils of the temperate region, reaching 20,000-400,000 ind. $/ \mathrm{m}^{2}$ (without specification of studied layer depth) (Schneider \& Maraun, 2005). In the world's fauna, oribatid mites are represented by more than 10,000 species, which are united into 1,240 genuses and 165 families ( $\mathrm{Su}-$ bías et al., 2012). Due to their morpho-ecological features they can live in forest floor litter, on the soil surface, in various soil horizons. Active nutrition of oribatids in floor litter and soil horizons with dead plant tissues provides soil enrichment with organic compounds and products of decomposition, influencing the soil's water-air properties and connected with successional changes in ecosystem (Badejo, 2004; Bird et al., 2004). Oribatid mites are one of few groups of soil saprophages which have the ability to consume coniferous litter (Striganova, 1980; Sylvain \& Buddle, 2010).

Although oribatid mites have always attracted the attention of researchers, the character of formation of their morpho-ecological composition in the forest recultivation plots in semiarid conditions in Ukraine is not well studied. The present study attempts to specify the morphoecological composition of oribatid mites in the floor litter of a red juniper plantation within the territory of the Western Donbass, which is part of the coal mining basin.

\section{Materials and methods}

The studied territory is located in the steppe zone of Ukraine in the Western Donbass - part of the basin situated in the territory of Dnipropetrovsk region (Fig. 1). Coal extraction is performed by open-pit mining technique. Flat piles in the mines of the Western Donbass contain several tens of millions of tons of phytotoxic sulfur, carbon containning and argillaceous shale, with high content of pyrite, troilite and chalcopyrite. When deep sediments of the Cretaceous period are moved onto the surface, this initiates the processes of physical weathering, oxidation, dissolution, hydrolysis, and burning. Other numerous negative factors may also induce these processes, such as high concentration of soluble toxic salts, alkalinity level rise, high soil density etc. (Novitskii, 2011).

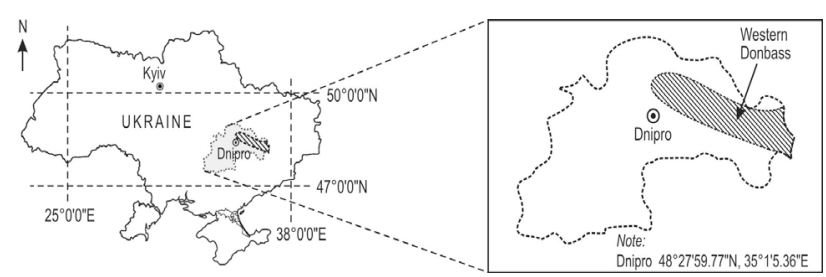

Fig. 1. Location of Western Donbass Coal Basin in Dnipropetrovsk region, Ukraine

The studied material was collected within the forest recultivation area under the red juniper (Juniperus virginiana L.) plantation located in the Western Donbass. The given experimental-production site of recultivation is located in the zone of "Pavlogradskaya" colliery fields $\left(48^{\circ} 33^{\prime} 32^{\prime \prime} \mathrm{N}, 35^{\circ} 59^{\prime} 13^{\prime \prime} \mathrm{E}\right)$ and represented by five stratigraphic types of bulk edaphotopes with different thickness of recultivation layers (Fig. 2). Trees and bushes, in particular red juniper - evergreen coniferous plant which belongs to the cypress family (Pinophyta: Cupressaceae), were planted at the stage of biological recultivation of the area. This popular ornamental plant is often used for recreational areas, as well as for agromelioration and forestry.

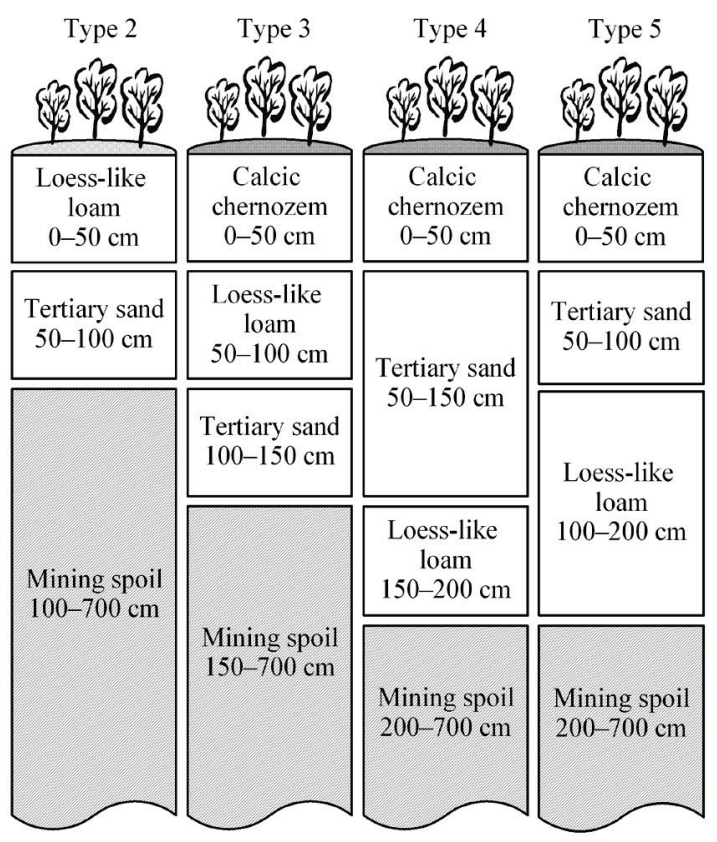

Fig. 2. Stratigraphic types of artificial edaphotopes within the experimental-production reclamation site

The research was performed in a recultivation plot with loess-like loam topsoil (type 2) and also in the plot with humified Calcic Chernozem topsoil (types 3 and 5). Types with Calcic Chernozem topsoil had different stratigraphic structure, were distanced from each other and there was no contact between given plots. The plot with Calcic Chernozem topsoil on the loess-like loam interlayer (type 3) was adjoined to the plot covered with loess-like loam and sand interlayer (type 2) and the plot with Calcic Chernozem topsoil on sand interlayer (type 5) was exposed to the natural environment as it is located close to the Samara River (Dnipropetrovsk region) and surrounded by ruderal and steppe grass vegetation. On the top layers of the given stratigraphic types were loess-like loam, which has potential fertility (type 2), and also the most fertile substrate - upper humified Calcic Chernozem layer (types 3, 4, 5) without any salinization signs. The main mass of tree roots usually could be found in the soil layer down to a depth of $60 \mathrm{~cm}$ while artificial topsoil thickness is limited to half a meter.

Collection of oribatids in the upper $10 \mathrm{~cm}$ layer of soil under the red juniper and their withdrawal was performed according to the generally accepted method (Bulanova-Zakhvatkina, 1967) in fifteen repeats. Spe- 
cies composition of oribatids was identified by microscopy, binocular microscopes PZO (Poland) and Zeiss Promo Star (Germany) were used. For identification of mites we used "Key to soil-inhabiting mites, Sarcoptiformes" (Giljarov, 1975) and "A guide to the Ceratozetoid mites (Oribatei, Ceratozetoidea) of Ukraine" (Pavlichenko, 1994) and "Checklist of the oribatid mites (Acariformes, Oribatida)...” (Subías et al., 2012). For identification of the domination structure in mite communities, the Engelmann scale was used (Shtirts, 2015): E - eudominant ( $>40 \%$ of general amount of individuals), D - dominant (12.5-39.9\%), SD - subdominant (4.0 $12.4 \%), \mathrm{R}$-recedent (1.3-3.9\%), SR - subrecedent $(<1.3 \%)$.

A wide variety of morphological forms is characteristic of oribatid mites. The features of oribatid morphology, as well as that of other soil microarthropods are connected with habitat conditions and indicate their association with some particular soil horizon. The result of analysis of adaptive (morpho-ecological) groups of oribatid mites can be one of those used for the assessments of biological diversity and their role in terrestrial ecosystems. We assigned six groups for oribatid mites (Krivolutsky, 1965): hydrobiont forms, soil surface inhabitants, small soil pore inhabitants, deep soil forms, floor litter inhabitants and unspecified forms. The latter are differentiated into primary unspecified and secondary unspecified forms . The results of the study are presented by using descriptive statistical procedures, which allow us to obtain a graphical representation of the data and a set of parameters that summarize important properties of the basic data.

\section{Results}

Affiliation to certain morpho-ecological (adaptive) groups is the indicator of importance for each particular species of oribatid mite in the species structure of biocenosis, along with its abundance (number of individuals per unit of occupied area); frequency (proportion of samples in which a species was identified to general amount of samples obtained from a given area in percentage); rate of domination (proportion of number of individuals of certain species to general number of individuals considered in the group). In general, these indicators are very important for evaluation of structure-functional characteristics of the animal community and can reflect the rate of naturalization of artificial forest plantations on recultivated areas.

Morpho-ecological groups of oribatids whose representatives were found in collected coniferous litter within the red juniper planation for four stratigraphic types of forest recultivation could be characterized as follows. Composition of adaptive groups of oribatids found in the coniferous litter

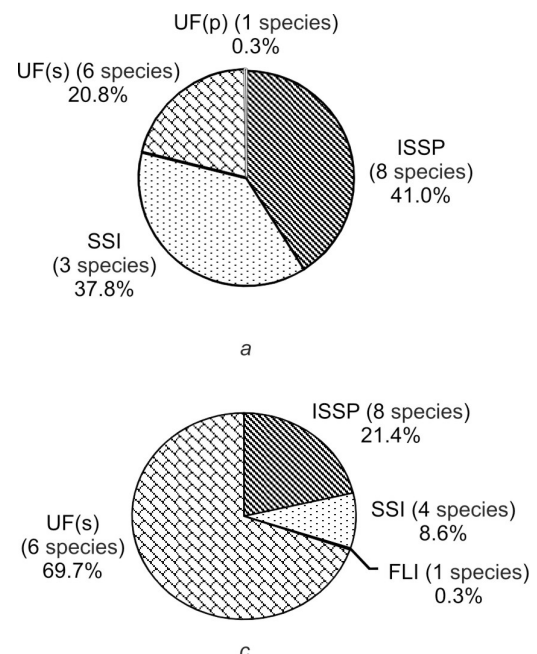

within the plot with loess-like loam topsoil had following features (Table 1). Within the given type the oribatid mite population was represented by four adaptive groups - soil surface inhabitants, small soil pore inhabitants and by primary and secondary unspecified forms. Deep soil forms and floor litter inhabitants were absent on this type. Species with high abundance (eudominants) were not specified in the structure. The oribatid mite community in the coniferous litter of the red juniper plantation within the studied stratigraphic types of forest recultivation was represented by such morpho-ecological groups as inhabitants of small soil pores, soil surface inhabitants, floor litter inhabitants, primary unspecified forms, secondary unspecified forms (Fig. 3).

\section{Table 1}

Morpho-ecologcial groups of oribatid mite community, collected in the coniferous litter of the red juniper plantation on loess-like loam topsoil with sand interlayer (second stratigraphic type) $(\mathrm{n}=1823$ ind., number of species -18 , average density $-12153 \mathrm{ind} . / \mathrm{m}^{2}$ )

\begin{tabular}{lccc}
\hline \multicolumn{1}{c}{ Species } & \multicolumn{3}{c}{ Adaptive Share of do- Domination } \\
& group & mination, $\%$ & class \\
\hline Belba dubinini Bulanova-Zachvatkina, 1962 & ISSP & 0.27 & SR \\
Liacarus punctulatus Mihelčič, 1956 & UF(s) & 0.27 & SR \\
Galumna dimorpha Krivolutskaja, 1952 & SSI & 26.90 & D \\
Gymnodamaeus bicostatus (Koch, 1835) & SSI & 9.40 & SD \\
Liochthonius lapponicus (Trägårdh, 1910) & UF(p) & 0.27 & SR \\
Rhinoppia obsoleta (Paoli, 1908) & ISSP & 0.44 & SR \\
Metabelba papillipes (Nicolet, 1855) & ISSP & 3.13 & R \\
Multioppia glabra (Mihelčić, 1955) & ISSP & 24.6 & D \\
Pilogalumna crassiclava crassiclava (Berlese, & SSI & 1.54 & R \\
1914) & & & \\
Protoribates capucinus Berlese, 1908 & UF(s) & 0.11 & SR \\
Punctoribates liber Paulitchenko, 1991 & UF(s) & 7.95 & SD \\
Ramusella mihelcici (Pérez-Iñigo, 1965) & ISSP & 1.92 & R \\
Scheloribates laevigatus (Koch, 1835) & UF(s) & 3.57 & R \\
Suctobelbella acutidens acutidens (Forsslund, & ISSP & 4.94 & SD \\
1941) & & & \\
S. sp. Jacot, 1937 & ISSP & 4.66 & SD \\
S. subtrigona (Oudemans, 1900) & ISSP & 1.10 & SR \\
Tectocepheus velatus velatus (Michael, 1880) & UF(s) & 8.55 & SD \\
Trichoribates trimaculatus (C. L. Koch, 1836) & UF(s) & 0.38 & SR \\
\hline
\end{tabular}

Note: adaptive group: ISSP - inhabitants of small soil pores, SSI - soil surface inhabitants, UF(p) - primary unspecified forms, UF(s) - secondary unspecified forms; $\mathrm{D}$ - dominants (12.5-39.9\% of bulk number of individuals), SD - subdominants (4.0-12.4\%), R - recedents (1.3-3.9\%), SR - subrecedents ( $<1.3 \%)$.

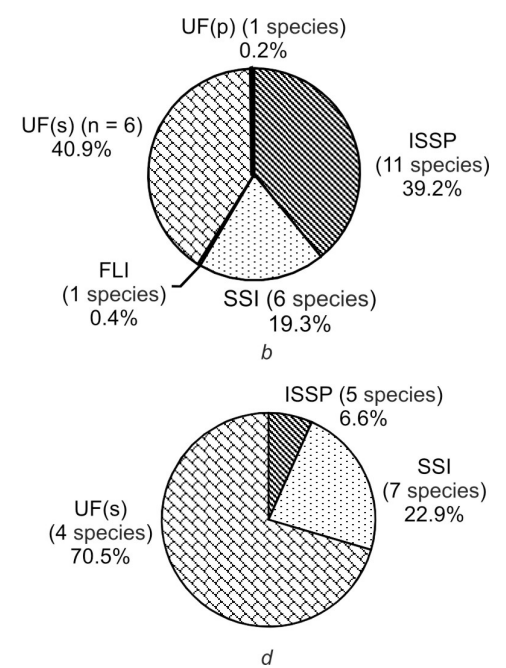

Fig. 3. Distribution of morpho-ecological groups of oribatid mite population in the coniferous litter within various stratigraphic types of forest recultivation: a - loess-like loam topsoil with sand interlayer (second stratigraphic type), $\mathrm{b}$ - humified Calcic Chernozem topsoil with loess-like loam interlayer $(0.5 \mathrm{~m})$ (third stratigraphic type of recultivation), $\mathrm{c}$ - humified Calcic Chernozem topsoil on sand interlayer $(1 \mathrm{~m})$ (fourth stratigraphic type of recultivation), $\mathrm{d}$ - humified Calcic Chernozem topsoil on sand interlayer $(0.5 \mathrm{~m})$ (fifth stratigraphic type of recultivation); ISSP - inhabitants of small soil pores, SSI - soil surface inhabitants, FLI - floor litter inhabitants, UF(p) - primary unspecified forms, UF(s) - secondary unspecified forms

Analysis of the composition of morpho-ecological groups of oribatid mites in the coniferous litter under red juniper planted in loess-like loam topsoil (type 2) indicated that the core of the oribatid population was represented by inhabitants of small soil pores and soil surface inhabitants (Fig. 1a). Inhabitants of small soil pores were represented by species with low abundance (subrecedents and recedents) as well as by 
species with high abundance (subdominants and dominants). In this adaptive group the dominant species Multioppia glabra (Mihelčič, $1955)$ had the highest abundance (24.6\%) (Table 2). Among soil surface inhabitants, in comparison with inhabitants of small soil pores, species with low abundance affiliated to subrecedents class were absent (Table 2). The dominant species Galumna dimorpha Krivolutskaja, 1952 had the highest abundance (26.9\%) in this adaptive group (Table 1).

\section{Table 2}

Distribution of morpho-ecological groups of oribatid mites according to domination classes in the coniferous litter covering loess-like loam (second stratigraphic type)

\begin{tabular}{lrrrrr}
\hline \multirow{2}{*}{$\begin{array}{c}\text { Abundance, } \\
\%\end{array}$} & \multicolumn{4}{c}{ Morpho-ecological group } & Total \\
\cline { 2 - 5 } & ISSP & \multicolumn{1}{c}{ SSI } & UF(s) & UF(p) & share, \\
\hline Dominants & 24.60 & 26.90 & 0.00 & 0.00 & 51.50 \\
Recedents & 5.05 & 1.54 & 3.57 & 0.00 & 10.16 \\
Subdominants & 9.60 & 9.40 & 16.50 & 0.00 & 35.50 \\
Subrecedents & 1.81 & 0.00 & 0.76 & 0.27 & 2.84 \\
Total share, \% & 41.06 & 37.84 & 20.83 & 0.27 & 100.00 \\
\hline
\end{tabular}

Note: ISSP - inhabitants of small soil pores, SSI - soil surface inhabitants, UF(p) primary unspecified forms, $\mathrm{UF}(\mathrm{s})$ - secondary unspecified forms.

The composition of adaptive groups of oribatids, identified in coniferous litter covering calcic chernozem topsoil on the loess-like loam interlayer (third stratigraphic type) (Table 3) had following features. The oribatid mite community was represented by such adaptive groups as soil surface inhabitants, inhabitants of small soil pores, floor litter inhabitants and unspecified forms. Deep soil forms were absent, high abundant species (eudominants) were not identified in the domination structure.

Analysis of the composition of morpho-ecological groups of oribatid mites in the coniferous litter under red juniper planted in Calcic Chernozem topsoil with loess-like loam interlayer (type 3) indicated that the core of the oribatid population was represented by secondary unspecified species (40.9\%) and small soil pore inhabitants (39.2\%) (Fig. 3b).

Among secondary unspecified forms in comparison to inhabitants of small soil pores in the coniferous litter of studied recultivation type, species with low abundance affiliated to the classes of subrecedents and recedents were absent (Table 4). In this adaptive group, two species of dominants Punctoribates liber Paulitchenko, 1991 (23.6\%) and Tectocepheus velatus velatus (Michael, 1880) (16.7\%) had the highest abundance (Table 3). Inhabitants of small soil pores found in the layer of coniferous litter within given type, mainly, were represented by species with high abundance (subdominants) (Table 4). In this adaptive group, subdominant species Multioppia glabra (Mihelčič, 1955) had the highest abundance (12.6\%).

The composition of morpho-ecological groups of oribatid mites in the coniferous litter covering Calcic Chernozem on the sand interlayer was as follows ( $1 \mathrm{~m}$ ) (fourth stratigraphic type) (Table 5). Such adaptive groups as soil surface inhabitants, inhabitants of small soil pores, floor litter inha- bitants and unspecified forms represented the oribatid mite population. As well as for previous types, deep soil forms were absent. In the domination structure among species with high abundance (subdominants and eudominants) only one eudominant species $(64.4 \%)$ and four subdominant species, which represented in total $27.9 \%$ of the oribatid population were identified. The analysis of morpho-ecological groups of oribatid mites in coniferous litter of red juniper planed in Calcic Chernozem topsoil on the sand interlayer $(1 \mathrm{~m})$ (type 4), indicated that the core of the oribatid mite population was represented by secondary unspecified forms (69.7\%) and small soil pore inhabitants (21.4\%) (Fig. 3c).

Among secondary unspecified forms in comparison with small soil pores inhabitants, such species of eudominants as Punctoribates liber Paulitchenko, 1991 mainly contributed (64.4\%) to formation of the oribatid community (Table 6). In this adaptive group, the bulk share of other species, affiliated to the subdominant and subrecedents categories was quite small - only $5.3 \%$ (Table 6).

Table 3

Morpho-ecological groups of oribatid mite community, collected in the coniferous litter of red juniper planted in humified Calcic Chernozem topsoil on loess-like loam interlayer (third stratigraphic type, $\mathrm{n}=$ 3556 ind., amount of species -25 , average density $-23707 \mathrm{ind} . / \mathrm{m}^{2}$ )

\begin{tabular}{|c|c|c|c|}
\hline Species & $\begin{array}{l}\text { Adaptive } \\
\text { group }\end{array}$ & $\begin{array}{l}\text { Share of do- } \\
\text { mination, } \%\end{array}$ & $\begin{array}{l}\text { omination } \\
\text { class }\end{array}$ \\
\hline Acrotritia hyeroglyphica (Berlese, 1916) & SSI & 0.39 & SR \\
\hline Belba dubinini Bulanova-Zachvatkina, 1962 & ISSP & 0.17 & SR \\
\hline Liacarus punctulatus Mihelčič, 1956 & $\mathrm{UF}(\mathrm{s})$ & 0.06 & SR \\
\hline Galumna dimorpha Krivolutskaja, 1952 & SSI & 5.48 & SD \\
\hline G. lanceata (Oudemans, 1900) & SSI & 0.09 & SR \\
\hline G. alata (Hermann, 1804) & SSI & 5.03 & SD \\
\hline Gymnodamaeus bicostatus (Koch, 1835) & SSI & 6.98 & $\mathrm{SD}$ \\
\hline Liochthonius lapponicus (Trägårdh, 1910) & $\mathrm{UF}(\mathrm{s})$ & 0.17 & SR \\
\hline Rhinoppia obsoleta (Paoli, 1908) & ISSP & 0.06 & SR \\
\hline Metabelba papillipes (Nicolet, 1855) & ISSP & 1.01 & SR \\
\hline Microzetorchestes emeryi (Coggi, 1898) & SSI & 0.09 & SR \\
\hline Multioppia glabra (Mihelčič, 1955) & ISSP & 12.60 & SD \\
\hline M. wilsoni laniseta Moritz, 1966 & ISSP & 0.14 & SR \\
\hline Oppiella nova (Oudemans, 1902) & ISSP & 0.39 & SR \\
\hline Oribatula frisiae (Oudemans, 1900) & UF(s) & 0.17 & SR \\
\hline Pilogalumna crassiclava crassiclava (Berlese, 1914) & 4) SSI & 1.69 & $\mathrm{R}$ \\
\hline Punctoribates liber Paulitchenko, 1991 & UF(s) & 23.60 & $\mathrm{D}$ \\
\hline Ramusella mihelcici (Pérez-Íñigo, 1965) & ISSP & 5.99 & SD \\
\hline Scheloribates laevigatus (Koch, 1835) & UF(s) & 0.23 & SR \\
\hline Suctobelbella alloenasuta Moritz, 1971 & ISSP & 1.52 & $\mathrm{R}$ \\
\hline S. acutidens acutidens (Forsslund, 1941) & ISSP & 5.40 & SD \\
\hline S. sp. Jacot, 1937 & ISSP & 10.6 & SD \\
\hline S. subtrigona (Oudemans, 1900) & ISSP & 1.27 & SR \\
\hline Tectocepheus velatus velatus (Michael, 1880) & $\mathrm{UF}(\mathrm{s})$ & 16.70 & $\mathrm{D}$ \\
\hline Trichoribates trimaculatus (C. L. Koch, 1836) & $\mathrm{UF}(\mathrm{s})$ & 0.17 & SR \\
\hline
\end{tabular}

Note: see Table 1.

Table 4

Distribution of morpho-ecological groups of oribatid mite according to domination classes in the coniferous litter covering Calcic Chernozem topsoil with loess-like loam interlayer (third stratigraphic type)

\begin{tabular}{|c|c|c|c|c|c|c|}
\hline \multirow{2}{*}{ Abundance, $\%$} & \multicolumn{5}{|c|}{ Morpho-ecological group } & \multirow{2}{*}{ Total share, $\%$} \\
\hline & ISSP & SSI & FLI & $\mathrm{UF}(\mathrm{s})$ & $\mathrm{UF}(\mathrm{p})$ & \\
\hline Dominants & 0.00 & 0.00 & 0.00 & 40.30 & 0.00 & 40.30 \\
\hline Recedents & 1.52 & 1.69 & 0.00 & 0.00 & 0.00 & 3.21 \\
\hline Subdominants & 34.59 & 17.49 & 0.00 & 0.00 & 0.00 & 52.08 \\
\hline Subrecedents & 3.04 & 0.18 & 0.39 & 0.63 & 0.17 & 4.41 \\
\hline Total share, $\%$ & 39.15 & 19.36 & 0.39 & 40.93 & 0.17 & 100.00 \\
\hline
\end{tabular}

Note: ISSP - inhabitants of small soil pores, SSI - soil surface inhabitants, FLI - floor litter inhabitants, UF(s) - secondary unspecified forms, UF(p) - primary unspecified forms.

Inhabitants of small soil pores were represented, mainly, by species with high abundance (subdominants) (Table 6). In this adaptive group two subdominant species Multioppia glabra (Mihelčič, 1955) (9.2\%) and Metabelba papillipes (Nicolet, 1855) (6.7\%) led in abundance (Table 5). Features of the composition of adaptive groups of oribatids found in coniferous litter covering Calcic Chernozem on the sand interlayer $(0.5 \mathrm{~m})$ (fifth stratigraphic type) (Table 7) were the following. Such adaptive groups as soil surface inhabitants along with small soil pore inhabitants and unspecified forms represented the oribatid mite population. Floor litter in- habitants and deep soil forms were not present. In the domination structure, species with very high abundance (eudominants) were not specified. Analysis of the composition of morpho-ecological groups for oribatid mites inhabiting coniferous litter under the red juniper planted in Calcic Chernozem topsoil on sand interlayer $(0.5 \mathrm{~m})$ (fifth stratigraphic type) indicated that the population's core is represented by secondary unspecified forms (70.4\%) and soil surface inhabitants (23.0\%) (Fig. 3d).

Among secondary unspecified forms, the main contribution (60.7\%) (Table 7) to formation of the oribatid community inhabiting coniferous 
litter for the given recultivation type was made by two dominant species Tectocepheus velatus velatus (Michael, 1880) (39.5\%) and Punctoribates liber Paulitchenko, 1991 (21.2\%). In this adaptive group, the bulk share of other species, subdominants and recedents was not significantonly $9.7 \%$ (Table 8 ).

\section{Table 5}

Morpho-ecological groups of oribatid mite community, collected in the coniferous litter of red juniper planted in humified Calcic Chernozem topsoil on the sand interlayer $(1 \mathrm{~m}$, fourth stratigraphic type, $\mathrm{n}=$ 3799 ind., amount of species -19 , average density -25327 ind. $/ \mathrm{m}^{2}$ )

\begin{tabular}{|c|c|c|c|}
\hline Species & $\begin{array}{l}\text { Adaptive } \\
\text { group }\end{array}$ & $\begin{array}{l}\text { Share of do- I } \\
\text { mination, } \%\end{array}$ & $\begin{array}{l}\text { omination } \\
\text { class }\end{array}$ \\
\hline Acrotritia hyeroglyphica (Berlese, 1916) & FLI & 0.26 & SR \\
\hline Galumna dimorpha Krivolutskaja, 1952 & SSI & 7.11 & SD \\
\hline G. lanceata (Oudemans, 1900) & SSI & 0.13 & SR \\
\hline Gymnodamaeus bicostatus (Koch, 1835) & SSI & 1.31 & $\mathrm{R}$ \\
\hline Litholestes altitudinis Grandjean, 1951 & SSI & 0.08 & SR \\
\hline Rhinoppia obsoleta (Paoli, 1908) & ISSP & 0.08 & SR \\
\hline Metabelba papillipes (Nicolet, 1855) & ISSP & 6.71 & SD \\
\hline Multioppia glabra (Mihelčič, 1955) & ISSP & 9.16 & $\mathrm{SD}$ \\
\hline Oribatula frisiae (Oudemans, 1900) & $\mathrm{UF}(\mathrm{s})$ & 0.08 & SR \\
\hline Protoribates capucinus Berlese, 1908 & UF(s) & 0.13 & SR \\
\hline Punctoribates liber Paulitchenko, 1991 & UF(s) & 64.4 & $\mathrm{E}$ \\
\hline Ramusella mihelcici (Pérez-Íñigo, 1965) & ISSP & 1.84 & $\mathrm{R}$ \\
\hline Scheloribates laevigatus (Koch, 1835) & $\mathrm{UF}(\mathrm{s})$ & 0.08 & SR \\
\hline Suctobelbella alloenasuta Moritz, 1971 & ISSP & 0.13 & SR \\
\hline S. acutidens acutidens (Forsslund, 1941) & ISSP & 1.31 & $\mathrm{R}$ \\
\hline S. sp. Jacot, 1937 & ISSP & 2.05 & $\mathrm{R}$ \\
\hline S. subtrigona (Oudemans, 1900$)$ & ISSP & 0.08 & SR \\
\hline Tectocepheus velatus velatus (Michael, 1880) & $\mathrm{UF}(\mathrm{s})$ & 4.95 & $\mathrm{SD}$ \\
\hline Trichoribates trimaculatus (C. L. Koch, 1836 ) & UF(s) & 0.13 & SR \\
\hline
\end{tabular}

Note: see Table 1.

\section{Table 6}

Distribution of morpho-ecological groups of oribatid mite population according to their domination classes on humified Calcic Chernozem soil surface on sand interlayer ( $1 \mathrm{~m}$, fourth stratigraphic type of recultivation)

\begin{tabular}{lrrrrr}
\hline \multirow{2}{*}{ Abundance, $\%$} & \multicolumn{5}{c}{ Morpho-ecological group } \\
\cline { 2 - 6 } & ISSP & SSI & FLI & UF(s) & total share, $\%$ \\
\hline Dominants & 0.00 & 0.00 & 0.00 & 64.40 & 64.40 \\
Recedents & 5.20 & 1.30 & 0.00 & 0.00 & 6.50 \\
Subdominants & 15.87 & 7.10 & 0.00 & 4.95 & 27.92 \\
Subrecedents & 0.29 & 0.21 & 0.26 & 0.42 & 1.18 \\
Total share, $\%$ & 21.36 & 8.63 & 0.26 & 69.77 & 100.00 \\
\hline
\end{tabular}

Note: ISSP - inhabitants of small soil pores, FLI - floor litter inhabitants, SSI soil surface inhabitants, $\mathrm{UF}(\mathrm{s})$ - secondary unspecified forms.

\section{Table 7}

Morpho-ecological groups of oribatid mite community, collected in the coniferous litter of red cedar planted in Calcic Chernozem topsoil on the sand interlayer $(0.5 \mathrm{~m}$, fifth stratigraphic type, $\mathrm{n}=708$ ind., number of species $=16$, average density $=4720 \mathrm{ind} . / \mathrm{m}^{2}$ )

\begin{tabular}{|c|c|c|c|}
\hline Species & $\begin{array}{l}\text { Adaptive } \\
\text { group }\end{array}$ & $\begin{array}{l}\text { Share of do } \\
\text { mination, } \%\end{array}$ & $\begin{array}{l}\text { omina- } \\
\text { on class }\end{array}$ \\
\hline Galumna alata (Hermann, 1804) & SSI & 1.41 & $\mathrm{R}$ \\
\hline G. dimorpha Krivolutskaja, 1952 & SSI & 1.84 & $\mathrm{R}$ \\
\hline G. lanceata (Oudemans, 1900) & SSI & 0.57 & SR \\
\hline Gymnodamaeus bicostatus (Koch, 1835) & SSI & 1.84 & $\mathrm{R}$ \\
\hline Metabelba papillipes (Nicolet, 1855) & ISSP & 3.11 & $\mathrm{R}$ \\
\hline Microzetorchestes emeryi (Coggi, 1898) & SSI & 0.28 & SR \\
\hline Multioppia glabra (Mihelčič, 1955) & ISSP & 2.12 & $\mathrm{R}$ \\
\hline Oribatula frisiae (Oudemans, 1900) & $\mathrm{UF}(\mathrm{s})$ & 6.07 & $\mathrm{SD}$ \\
\hline Pilogalumna crassiclava crassiclava (Berlese, 1914) & SSI & 16.70 & $\mathrm{D}$ \\
\hline Punctoribates liber Paulitchenko, 1991 & UF(s) & 21.20 & $\mathrm{D}$ \\
\hline Suctobelbella acutidens acutidens (Forsslund, 1941) & ISSP & 0.85 & SR \\
\hline S. subtrigona (Oudemans, 1900) & ISSP & 0.28 & SR \\
\hline$S$. sp. & ISSP & 0.28 & SR \\
\hline Tectocepheus velatus velatus (Michael, 1880) & $\mathrm{UF}(\mathrm{s})$ & 39.50 & $\mathrm{D}$ \\
\hline Trichoribates trimaculatus (C. L. Koch, 1836) & UF(s) & 3.67 & $\mathrm{R}$ \\
\hline Xenillus tegeocranus (Hermann, 1804) & SSI & 0.28 & SR \\
\hline
\end{tabular}

Note: see Table 1.

Inhabitants of the soil surface, as well as in case with secondary unspecified forms, were mainly represented by species with high abun- dance (dominants), their share in the total abundance was $16.7 \%$ (Table 8). In this adaptive group, only the dominant species Pilogalumna crassiclava crassiclava (Berlese, 1914) had the highest abundance (16.7\%) (Table 7).

\section{Table 8}

Distribution of morpho-ecological groups of oribatid mites according to domination classes, on Calcic Chernozem topsoil on the sand interlayer ( $0.5 \mathrm{~m}$, fifth stratigraphic type)

\begin{tabular}{lrrrr}
\hline \multirow{2}{*}{\multicolumn{1}{c}{ Abundance, \% }} & \multicolumn{4}{c}{ Morpho-ecological group } \\
\cline { 2 - 5 } & ISSP & \multicolumn{1}{c}{ SSI } & UF(s) & total share, \% \\
\hline Dominants & 0.00 & 16.70 & 60.70 & 77.40 \\
Recedents & 5.23 & 5.09 & 3.67 & 13.99 \\
Subdominants & 0.00 & 0.00 & 6.07 & 6.07 \\
Subrecedents & 1.41 & 1.13 & 0.00 & 2.54 \\
Total share, \% & 6.64 & 22.92 & 70.44 & 100.00 \\
\hline
\end{tabular}

Note: ISSP - inhabitants of small soil pores; SSI - soil surface inhabitants; UF(s) secondary unspecified forms.

\section{Discussion}

Summarizing all the above, it should be noted that forest floor litter thanks to a number of physical properties of its structure - non-high density, loose composition, saturation with various gases, high air and water permeability, increased heat capacity, creates a specific ecological environment influencing all vital aspects of its biota. Although floor litter covers soil and through biochemical and physical pathways transforms part of its resources and energy into soil, it is an independent biogeohorizon connecting phytocenosis and soil (Chornobai, 2000; Ospina-Bautista \& Estévez Varón, 2016; Krishna \& Mohan, 2017). It serves a number of functions as soil horizon: holds roots and rhizomes of forest plants, it is inhabited by many invertebrate animals, which make vertical migrations and promote formation of the biogenic profile of forest soils by their activity. Within the forest recultivation plot, in the steppe zone, where forest is not only geographically anomalous, but often subject to ecological inconsistency with the environment, the importance of forest floor litter is significantly increasing. Among the soil animals that play an important role in the transformation of forest litter and the formation of soil humus, such representatives as armoured mites-oribatids (Acariformes, Oribatida) should be distinguished (Hättenschwiler et al., 2005; Didur et al., 2018b; Marian et al., 2018; Ojeda \& Gasca-Pineda, 2019). In the course of its evolution, this taxonomic group has developed a number of morphological adaptations for movement in substrates. In scope of our study in the floor litter under red juniper plantation within semiarid conditions of the steppe zone of Ukraine, representatives of four life forms of oribatids: soil surface inhabitants, inhabitants of small soil pores, floor litter inhabitants and unspecified forms were found, deep soil forms were not identified.

Some researchers (Marian et al., 2018; Bluhm et al., 2019) showed that the species richness of oribatid mites does not depend on the litter belonging to a particular tree species. Both species richness and activity of oribatid correlates with the organic carbon content in the soil substrate (Jakšová et al., 2019). Our study clearly manifested these regularities. Thus, a higher average density and a greater number of species is observed for litter in the third $\left(23,707\right.$ ind. $/ \mathrm{m}^{2}, 25$ species) and fourth $\left(25,326.7 \mathrm{ind} . \mathrm{m}^{2}, 19\right.$ species) stratigraphic (chernozem) types of bulk edaphotopes. An exception is the population of the litter of the fifth type (Calcic Chernozem topsoil on the sand interlayer), where the average density of the population of oribatids and the number of species is the smallest $\left(4,720 \mathrm{ind} . / \mathrm{m}^{2}, 16\right.$ species) both in comparison with other litter of chernozem stratigraphic types and in comparison with the litter from the second stratigraphic type with a bulk loess-like loam $\left(12,153\right.$ ind. $/ \mathrm{m}^{2}$, 18 species). It is explained by the fact that the tree plantation of red juniper in the fifth stratigraphic type experiences, on the one hand, the influence of the external environment (the proximity of the Samara River, the environment of ruderal and steppe grassy vegetation), and on the other, anthropogenic influence, with nonauthorized tree cutting and, as a result, the destruction of forest litter. Soil invertebrates also fill important niches in the environment because they influence nutrient flow, 
improve soil aeration and fertility, and alter plant community structure (Riggins et al., 2009). Estimation of abundance is a basic task in analyzing the dynamics of wildlife populations. The information on population abundance is also crucial to scientific management of wildlife ( $\mathrm{Hu}-$ apeng et al., 1997). It is important for such functional groups of invertebrates as ecosystem engineers. Their abundance in soils of undisturbed terrestrial ecosystems is quite significant and for oribatids can reach up to 400,000 ind. $/ \mathrm{m}^{2}$ in some cases (Schneider \& Maraun,
2005). In our research, oribatids with high-abundant species (dominants) in the juniper coniferous litter covering loess-like loam topsoil were represented (Fig. 4) by inhabitants of small soil pores (24.6\%) and soil surface inhabitants (26.9\%), while for the other three Calcic Chernozem types the share of given forms sharply decreased or they were absent, and share of unspecified forms increased at the same time up to $40.3 \%$ for loess-like loam interlayer type, for 1 meter sand interlayer type $-64.4 \%$, for $0.5 \mathrm{~m}$ sand interlayer type $-60.7 \%$.
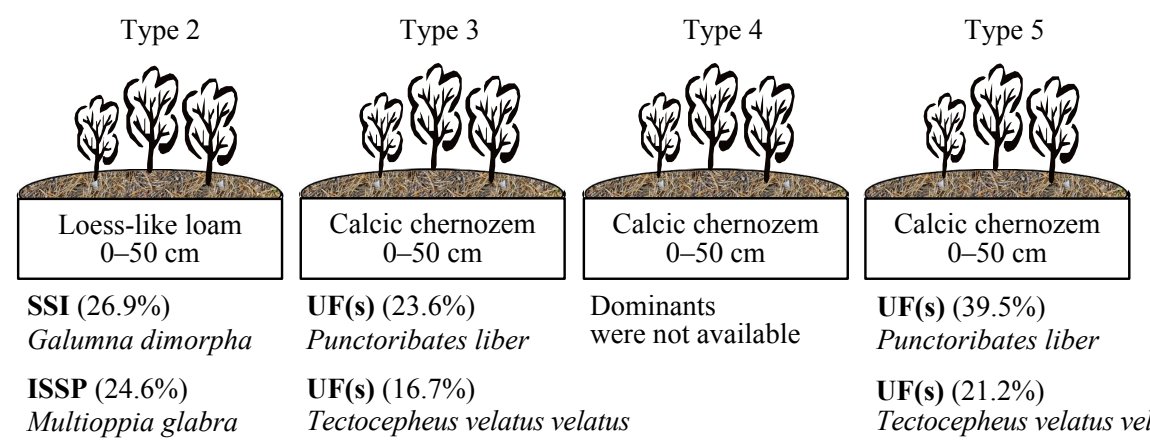

UF(s) $(21.2 \%)$

Tectocepheus velatus velatus

SSI (16.7\%)

Pilogalumna crassiclava

crassiclava

Fig. 4. Distribution of morpho-ecological groups of oribatid mite population with high abundance (dominants) in the coniferous litter within various stratigraphic types of forest recultivation: $a$ - loess-like loam topsoil with sand interlayer (type 2), $b$-humified Calcic Chernozem topsoil with loess-like loam interlayer ( $0.5 \mathrm{~m}$, type 3$), c$-humified Calcic Chernozem topsoil on sand interlayer ( $1 \mathrm{~m}$, type 4$), d$-humified Calcic Chernozem topsoil on sand interlayer ( $0.5 \mathrm{~m}$, type 5); ISSP - inhabitants of small soil pores, SSI - soil surface inhabitants, UF(s) - secondary unspecified forms

\section{Conclusions}

The activity of oribatid mites in terrestrial ecosystems is associated with participation in the transformation of phytodetrites and corresponds to such types of ecosystem services as soil formation and nutrient turnover. On the sites of forest recultivation, such ecosystem engineers as oribatid mites, due to their significant abundance and variety of their morphoecological forms, cover the entire litter layer as an independent biogeohorizon. They perform their geochemical function, participating in the nutrients' turnover, and, in general, in optimization of biogeochemical cycles of forest ecosystems at the biological stage of forest recultivation, causing impact on the productivity of reclaimed soils, while maintaining the stability of the ecological properties of bulk reclaimed soils - fertility and structure, contributing to further ecological rehabilitation of technogenicallydisturbed landscapes.

When comparing the spectra of adaptive groups of oribatid mites on different stratigraphic types of forest reclamation single tree plots, it was established that the communities of oribatids formed in juniper litter significantly differ in their morpho-ecological features. Thus, in the litter of the reclamation plot that had no humus (loess-like loam topsoil), such adaptive groups as inhabitants of small soil pores and topsoil inhabitants were prevalent. In the juniper litter on the studied calcic chernozem topsoils, the total proportion of these adaptive forms decreases from the stratigraphic type with loess-likes loam interlayer (the third type - 58.5\%) to the type with a half-meter layer of sand (the fifth type $-29.5 \%$ ), while the share of unspecialized forms increases from $40.9 \%$ to $70.4 \%$ respectively.

The authors would like to thank the oribatologist, associate professor Arthur Shtirts, $\mathrm{PhD}$, for his assistance in identifcation of collected zoological samples.

\section{References}

Amossé, J., Turberg, P., Kohler-Milleret, R., Gobat, J.-M. \& Le Bayon, R.-C. (2015). Effects of endogeic earthworms on the soil organic matter dynamics and the soil structure in urban and alluvial soil materials. Geoderma, 243244, 50-57.

Badejo, M. A., de Aquino, A. M., de-Polli, H., \& Correia, M. E. F. (2004). Response of soil mites to organic cultivation in an ultisol in southeast Brazil. Experimental and Applied Acarology, 34(3-4), 345-365.

Benbrahim, K. F., Ismaili, M., Benbrahim, S. F., \& Tribak, A. (2004). Land degradation by desertification and deforestation in Morocco. Sécheresse, 15(4), 307-320.
Berke, S. K. (2010). Functional groups of ecosystem engineers: a proposed classification with comments on current issues. Integrative and Comparative Biology, 50(2), 147-157.

Bertram, C., \& Rehdanz, K. (2015). The role of urban green space for human well-being. Ecological Economics, 120, 139-152.

Bird, S. B., Coulson, R. N., \& Fisher, R. F. (2004). Changes in soil and litter arthropod abundance following tree harvesting and site preparation in a loblolly pine (Pinus taeda L.) plantation. Forest Ecology and Management, 202(1-3), 195-208.

Blouin, M., Hodson, M. E., \& Delgado, E. A. (2013). A review of earthworm impact on soil function and ecosystem services. European Journal of Soil Science, 64(1), 161-182.

Bluhm, C., Butenschoen, O., Maraun, M., \& Scheu, S. (2019). Effects of root and leaf litter identity and diversity on oribatid mite abundance, species richness and community composition. PLoS One, 14(7), e0219166.

Borrellia, P., Panagosa, P., Langhammer, J., Apostol, B., \& Schütt, B. (2016). Assessment of the cover changes and the soil loss potential in European forestland: First approach to derive indicators to capture the ecological impacts on soil-related forest ecosystems. Ecological Indicators, 60, 1208-1220.

Brygadyrenko, V. V. (2016). Vplyv potuzhnosti pidstylky na strukturu pidstylkovoi mezofauny shyrokolystianykh lisiv stepovoi zony Ukrainy [Influence of litter thickness on the structure of litter macrofauna of deciduous forests of Ukraine's steppe zone]. Visnyk of Dnipropetrovsk University, Biology, Ecology, 24(1), 240-248 (in Ukrainian).

Bulanova-Zakhvatkina, E. M. (1967). Pantsimyie kleschi-oribatidyi [Oribatid mites]. Vysshaya Shkola, Moscow (in Russian).

Byers, J. E., Cuddington, K., Jones, C. G., Talley, T. S., Hastings, A., Lambrinos, J. G., Crooks, J. A., \& Wilson, W. G. (2006). Using ecosystem engineers to restore ecological systems. Trends in Ecology and Evolution, 21, 493-500.

Cameron, E. K., Proctor, H. C., \& Bayne, E. M. (2013). Effects of an ecosystem engineer on belowground movement of microarthropods. PLoS One, 8(4), e62796.

Chakravarty, S., Ghosh, S. K., Suresh, C. P., Dey, A. N., \& Shukla, G. (2012). Deforestation: Causes, effects and control strategies. In: Okia, C. A. (Ed.). Global perspectives on sustainable forest management. InTech. Pp. 3-28.

Chibrik, T. S., Lukina, N. V., Filimonova, E. I., Glazyrina, M. A., Rakov, E. A., Maleva, M. G., \& Prasad, M. N. V. (2016). Biological recultivation of mine industry deserts: Facilitating the formation of phytocoenosis in the Middle Ural region, Russia. In: Prasad, M. N. V. (Ed.). Bioremediation and Bioeconomy. Elsevier. Pp. 389-418.

Chornobai, Y. N. (2000). Forest ecosystems is the most important factor of ecological situation optimization on degraded lands [Plant detritus transformation in the natural ecosystems]. State Natural History Museum of Ukrainian Academy of Sciences Publishers, Lviv (in Ukrainian).

Cunha, L., Brown, G. G., Stanton, D. W. G., Da Silva, E., Hansel, F. A., Jorge, G., McKey, D., Vidal-Torrado, P., Macedo, R. S., Velasquez, E., James, S. W., 
Lavelle, P., Kille, P., \& the Terra Preta de Indio Network (2016). Soil animals and pedogenesis: The role of earthworms in anthropogenic soils. Soil Science, 181(3/4), 110-125.

de Visser, S., Thébault, E., \& de Ruiter, P. C. (2013). Ecosystem engineers, keystone species. In: Leemans, R. (Eds.). Ecological systems. Springer, New York. Pp. 59-68.

de Waroux, Y. P., \& Lambin, E. F. (2012). Monitoring degradation in arid and semi-arid forests and woodlands: The case of the argan woodlands (Marocco). Applied Geography, 32, 777-786.

Didur, O. O., Kulbachko, Y. L., \& Pakhomov, O. Y. (2018b). Species structure of oribatid mite population (Acari, Oribatea) in the forest floor litter in the reclaimed territories (Ukraine). Vestnik Zoologii, 52(4), 331-340.

Didur, O., Kulbachko, Y. Ovchynnykova, Y., Pokhylenko, A., Lykholat, T. (2019). Zoogenic mechanisms of ecological rehabilitation of urban soils of the park zone of megapolis: Earthworms and soil buffer capacity. Journal of Environmental Research, Engineering and Management, 75(1), 24-33.

Didur, O., Kulbachko, Y., \& Maltsev, Y. (2018a). Impact of tropho-metabolic activity of earthworms (Lumbricidae) on distribution of soil algae within Acer platanoides L. plantation in recultivated territories of Western Donbass (Ukraine). Ukrainian Journal of Ecology, 8(2), 18-23

Eisenhauer, N. (2010). The action of an animal ecosystem engineer: Identification of the main mechanisms of earthworm impacts on soil microarthropods. Pedobiologia, 53(6), 343-352.

Faly, L. I., \& Brygadyrenko, V. V. (2014). Patterns in the horizontal structure of litter invertebrate communities in windbreak plantations in the steppe zone of the Ukraine. Journal of Plant Protection Research, 54(4), 414420.

Faly, L. I., Kolombar, T. M., Prokopenko, E. V., Pakhomov, O. Y., \& Brygadyrenko, V. V. (2017). Structure of litter macrofauna communities in poplar plantations in an urban ecosystem in Ukraine. Biosystems Diversity, 25(1), 29-38.

Giljarov, M. S. (Ed.). (1975). Opredelitel obitayuschih v pochve kleschey (Sarcoptiformes) [Key to soil-inhabiting mites, Sarcoptiformes]. Nauka, Moscow (in Russian).

Gormsen, D., Hedlund, K., \& Huifu, W. (2006). Diversity of soil mite communities when managing plant communities on set-aside arable land. Applied Soil Ecology, 31, 147-158.

Grimaldi, M., Jiménez, J. J., McKey, D., Mathieu, J., Velasquez, E., \& Zangerlé, A. (2016). Ecosystem engineers in a self-organized soil: A review of concepts and future research questions. Soil Science, 181(3/4), 91-109.

Gudym, N. G. (2016). Sezonna dynamika chyselnosti Brachyiulus jawlowskii (Diplopoda, Julidae) na areni r. Dnipro [Seasonal population dynamics of Brachyiulus jawlowskii (Diplopoda, Julidae) in the Dnieper river arena]. Visnyk of Dnipropetrovsk University, Biology, Ecology, 24(2), 489-494 (in Ukrainian).

Hättenschwiler, S., Tiunov, A. V., \& Scheu, S. (2005). Biodiversity and litter decomposition in terrestrial ecosystems. Annual Review of Ecology, Evolution, and Systematics, 36, 191-218.

Huapeng, C., Feng, L., Huai, W., Jianzhang, M., Xibo, J., Chunmei, L., \& Kelan, X. (1997). Assessment of three methods for estimating abundance of ungulate populations. Journal of Forestry Research, 8(2), 111-114.

Ibarra, J. M. N., \& de las Heras, M. M. (2005). Open-cast mining reclamation. In: Mansourian, S., Vallauri, D., \& Dudley, N. (in cooperation with WWF International). Forest restoration in landscapes: Beyond planting trees. Springer, New York. Pp. 370-376.

Jakšová, P., Luuptáčik, P., \& Miklisová, D. (2019). Distribution of Oribatida (Acari) along a depth gradient in forested scree slopes. Subterranean Biology, 31, $29-48$.

Jouquet, P., Blanchart, E., \& Capowiez, Y. (2014). Utilization of earthworms and termites for the restoration of ecosystem functioning. Applied Soil Ecology, $73,34-40$.

Khromykh, N., Lykholat, Y., Shupranova, L., Kabar, A., Didur, O., Lykholat, T., \& Kulbachko, Y. (2018). Interspecific differences of antioxidant ability of introduced Chaenomeles species with respect to adaptation to the steppe zone conditions. Biosystems Diversity, 26(2), 132-138.

Kitz, F., Steinwandter, M., Traugott, M., \& Seeber, J. (2015). Increased decomposer diversity accelerates and potentially stabilises litter decomposition. Soil Biology and Biochemistry, 82, 138-141.

Klymenko, G., Kovalenko, I., Lykholat, Y., Khromykh, N., Didur, O., \& Alekseeva, A. (2017). Intehralna otsinka stanu populiatsii ridkisnykh vydiv roslyn [The integral assessment of the rare plant populations]. Ukrainian Journal of Ecology, 7(2), 201-209 (in Ukrainian).

Kolodochka, L. A., \& Shevchenko, O. S. (2013). Diversity and community structure of Oribatid mites (Acari, Oribatei) at memorial complexes of a megapolis. Vestnik Zoologii, 47(4), 291-297.

Krishna, M. P., \& Mohan, M. (2017). Litter decomposition in forest ecosystems: A review. Energy, Ecology and Environment, 2(4), 236-249.

Krivolutsky, D. A. (1965). Morfo-ekologicheskie tipyi pantsirnyih kleschey (Acariformes, Oribatei) [Morpho-ecological types of oribatid mites (Acariformes, Oribatei)]. Journal of Zoology, 44, 1176-1189 (in Russian).
Lavelle, P., Spain, A., Blouin, M., Brown, G., Decaëns, T., Grimaldi, M., Jiménez, J. J., McKey, D., Mathieu, J., Velasquez, E., \& Zangerlé, A. (2016). Ecosystem engineers in a self-organized soil: A review of concepts and future research questions. Soil Science, 181(3/4), 91-109.

Lykholat, T., Lykholat, O., \& Antonyuk, S. (2016). Immunohistochemical and biochemical analysis of mammary gland tumours of different age patients. Cytology and Genetics, 50(1), 32-41.

Lykholat, Y. V., Khromykh, N. O., Pirko, Y. V., Alexeyeva, A. A., Pastukhova, N. L., \& Blume, Y. B. (2018b). Epicuticular wax composition of leaves of Tilia L. trees as a marker of adaptation to the climatic conditions of the steppe Dnieper. Cytology and Genetics, 52(5), 323-330.

Lykholat, Y., Khromykh, N., Didur, O., Alexeyeva, A., Lykholat, T., \& Davydov, V. (2018a). Modeling the invasiveness of Ulmus pumila in urban ecosystems under climate change. Regulatory Mechanisms in Biosystems, 9(2), 161-166.

Marian, F., Sandmann, D., Krashevska, V., Maraun, M., \& Scheu, S. (2018). Altitude and decomposition stage rather than litter origin structure soil microarthropod communities in tropical montane rainforests. Soil Biology and Biochemistry, 125, 263-274.

Mbaya, R. P. (2013). Land degradation due to mining: The Gunda scenario. International Journal of Geography and Geology, 2(12), 144-158.

Mori, A. S., Lertzman, K. P., \& Gustafsson, L. (2017). Biodiversity and ecosystem services in forest ecosystems: A research agenda for applied forest ecology. Journal of Applied Ecology, 54(1), 12-27.

Nazarenko, M., Lykholat, Y., Grigoryuk, I., \& Khromykh, N. (2018). Optimal doses and concentrations of mutagens for winter wheat breeding purposes. Part I. Grain productivity. Journal of Central European Agriculture, 19(1), 194-205.

Novitskii, M. L. (2011). Granulometricheskij sostav melkozema sulfidnoj gornoj porody i tehnogennyh substratov shahtnyh otvalov [Granulometric texture of sulfide subsurface rock fine grained soil and mine spoil technogenic substrates]. Bulletin of the Nikitsky Botanical Garden, 103, 85-87 (in Russian).

Ojeda, M., \& Gasca-Pineda, J. (2019) Abundance and diversity of the soil microarthropod fauna from the Cuatro Ciénegas Basin. In: Álvarez, F., Ojeda, M. (Eds.). Animal diversity and biogeography of the Cuatro Ciénegas Basin. Cuatro Ciénegas Basin: An endangered hyperdiverse oasis. Springer, Cham. Pp. 29-51

Ospina-Bautista, F., \& Estévez Varón, J. V. (2016). Plant structure predicts leaf litter capture in the tropical montane bromeliad Tillandsia turneri. Brazilian Journal of Biology, 76(3), 686-691.

Pavlichenko, P. G. (1994). Opredelitel tseratozetoidnyih kleschey (Oribatei, Ceratozetoidea) Ukrainyi [A guide to the Ceratozetoid mites (Oribatei, Ceratozetoidea) of Ukraine]. I. I. Schmalhausen Institute of Zoology of National Academy of Sciences of Ukraine, Kiev (in Russian).

Pertseva, T. A., Lykholat, E. A., \& Gurzhiy, E. V. (2008). Vliyanie tiotropiya bromida na sostoyanie mukociliarnogo klirensa u bol'nyh hronicheskim obstruktivnym zabolevaniem legkih [The influence of tiotropium bromide on mucociliary clearance's condition in patients with chronic obstructive pulmonary disease]. Ukrainian Pulmonology Journal, 1, 13-15 (in Ukrainian).

Pokhylenko, A., Lykholat, O., Didur, O., Kulbachko, Y., \& Lykholat, T. (2019). Morphological variability of Rossiulus kessleri (Diplopoda, Julida) from different biotopes within Steppe Zone of Ukraine. Ukrainian Journal of Ecology, 9(1), 176-182.

Riggins, J. J., Davis, C. A., \& Hoback, W. W. (2009). Biodiversity of belowground invertebrates as an indicator of wet meadow restoration success (Platte River, Nebraska). Restoration Ecology, 17(4), 495-505.

Schneider, K., \& Maraun, M. (2005). Feeding preferences among dark pigmented fungal taxa ("Dematiacea") indicate limited trophic niche differentiation of oribatid mites (Oribatida, Acari). Pedobiologia, 49, 61-67.

Seniczak, S., Kaczmarek, S., Seniczak, A., \& Rraczyk, R. (2012). Oribatid mites (Acari, Oribatida) of open and forested habitats of Korčula Island (Croatia). Biological Letters, 49(1), 27-34.

Shtirts, A. D. (2015). Ekologicheskaya struktura naseleniya pancimyh kleshej (karer “'Osnovnoj”, Doneckaya oblast) [The ecological structure of oribatid mites population (“'Osnovnoy” quarry, Donetsk region)]. Biological Bulletin of Bogdan Chmelnitskiy Melitopol State Pedagogical University, 5(2), 16-30.

Shtirts, A. D. (2015). Ocenka vliyaniya antropogennoj nagruzki na ekosistemy s ispolzovaniem integralnogo pokazatelya soobshestv pancimyh kleshej [Evaluation of anthropogenic pressures on ecosystems by using of the integral oribatid mites community's index]. Acta Biologica Sibirica, 1, 51-66. (in Russian).

Shulman, M. V., Pakhomov, O. Y., \& Brygadyrenko, V. V. (2017). Effect of lead and cadmium ions upon the pupariation and morphological changes in Calliphora vicina (Diptera, Calliphoridae). Folia Oecologica, 44(1), 28-37.

Sjursen, H., Michelsen, A., \& Holmstrup, M. (2005). Effects of freeze-thaw cycles on microarthropods and nutrient availability in a sub-Arctic soil. Applied Soil Ecology, 28(1), 79-93.

Smrž, J., \& Norton, R. A. (2004). Food selection and internal processing in Archegozetes longisetosus (Acari: Oribatida). Pedobiologia, 48(2), 111-120. 
Stott, D. E., \& Moebius-Clune, B. N. (2017). Soil health: Challenges and opportunitie. In: Field, D. J., Morgan, C. L. S., \& McBratney, A. B. (Eds.). Global soil security. Progress in soil science. Springer, Cham. Pp. 109-121.

Striganova, B. R. (1980). Pitanie pochvennyh saprofagov [Feeding of soil saprophages]. Nauka, Moscow (in Russian).

Subías, L. S., Shtanchaeva, U. Y., \& Arillo, A. (2012). Listado de los ácaros oribátidos (Acariformes, Oribatida) de las diferentes regiones biogeográficas del mundo [Checklist of the oribatid mites (Acariformes, Oribatida) of the different world biogeographical regions]. Electronic Monograph (in Spanish).

Sylvain, Z. A., \& Buddle, C. M. (2010). Effects of forest stand type on oribatid mite (Acari: Oribatida) assemblages in a Southwestern Quebec forest. Pedobiologia, 53(5), 321-325.
Toth, Z., Hornung, E., Baldi, A., \& Kovacs-Hostyanszki, A. (2016). Effects of setaside management on soil macrodecomposers in Hungary. Applied Soil Ecology, 99, 97-105.

Walter, D. E., \& Proctor, H. C. (2013). Mites: Ecology, evolution, and behaviour. 2nd ed. Springer Netherlands.

Wehner, K., Heethoff, M., \& Brückner, A. (2018). Seasonal fluctuation of oribatid mite communities in forest microhabitats. PeerJ, 6, e4863.

Zimmer, M., \& Topp, W. (1998). Microorganisms and cellulose digestion in the gut of the woodlise Porcellio scaber. Journal of Chemical Ecology, 24(8), 1397-1408. 